DOI 10.36622/VSTU.2020.47.3.003

UDC $697.33: 697.34$

A. V. Loboda ${ }^{1}$, A. A. Chuikina ${ }^{2}$

\title{
ABOUT THE ALIGNMENT DESIGN OF HEAT SUPPLY SYSTEMS ON THE BASIS OF SYSTEM ANALYSIS
}

Voronezh State Technical University ${ }^{1,2}$

Russia, Voronezh

\footnotetext{
${ }^{1}$ D. Sc. in Physics and Mathematics, Prof. of the Dept. of Applied Mathematics and Mechanics,

e-mail:lobvgasu@yandex.ru

${ }^{2}$ PhD student of the Dept. of Heat Supply and Oil and Gas Business, e-mail: teplosnab_kaf@vgasu.vrn.ru
}

\begin{abstract}
Statement of the problem. The aim of the article is to develop procedures for translating practical questions about the choice of optimal routes of the heat supply system into mathematical problems of multi-criteria optimization and the study of these problems taking into account a large number of different parameters of the system and their connections.
\end{abstract}

Results and conclusions. A mathematical description is compiled of the route choosing problem for the heat supply system based on the methods of system analysis. As optimized criteria, the integrated parameters are discussed describing the main characteristics of the systems under consideration. Unification of the problem where some of the criteria must be minimized and the other one maximized is carried out by replacing the minimized criteria with inverse values. Using the example of the modeling problems the procedures are shown for finding optimal solutions. The visibility of such procedures is provided by the use of a quadratic (Euclidean) norm instead of the traditional summation of weight coefficients. The importance of correct scaling and choice of weight factors is shown in the study of the discussed multi-criteria optimization problem.

Keywords: heat supply, optimality criteria, optimal route, optimization of heating main parameters.

Introduction. The solution of practical problems in the design of heat supply systems is commonly accompanied by the need to identify the best solution, i.e., it choice of the type of thermal insulation and its characteristics, determination of the optimal pressure drop, expediency of connecting an additional group of consumers to a heating network, etc. All these tasks can be attributed to optimization problems addressed by lots of domestic and foreign scientists, e.g., $[8,15-18]$. 
These studies typically look at the search for optimal system parameters such as pressure, heat losses, temperature, etc. This being the case, the existing engineering calculation methods assume the presence of a completed design calculation (at least the results of a hydraulic calculation). This makes it imperative to carry out a significant amount of calculations, and thus takes a lot of time and labor costs.

As one of the main stages in the design of heat supply systems is precisely the design of the pipeline network [7, 22], the above features make it difficult to choose the best (optimal) option for routing the projected network. A possible solution can be found when considering the optimization problem at the initial design stage (without carrying out a constructive calculation) with further coordination of the main design stages. Obviously, this approach limits the list of initial data and solutions should be searched for by means of aggregated indicators.

The search for the optimal route for laying heat pipelines is an applied problem of system analysis, while optimization is mainly performed according to any parameter [7]. An incorrect choice of such a parameter might result in a decision that obviously does not suit a customer and engineer for a number of other reasons [13]. In addition, the number of options for laying such networks can be in thousands, and from this variety a small number of optimal (or close to optimal) options are to be selected. Therefore the relevance of the theoretical consideration of the multi-criteria optimization problem for considering the most significant parameters that affect the obtaining the best route of the designed heat pipelines.

1. Enlarged parameters and selection of the optimal heat supply route. Let us explore the effect of tracing the pipeline network of the heat supply system shown in Fig. 1 on the main parameters of the network.

In modern practice, the study of the structure of the pipeline network with incomplete information about the system is typically performed according to enlarged indicators. The most significant of them are the material characteristics of a heating network, moment of heat load and annual heat losses [6,9-11, 14, 20,21]. Although there is currently no agreement as to how to determine the most reliable dependences of these parameters on the external data of the problem, the above studies suggest that it is advisable that the material characteristic of the network are calculated using the formula

$$
M=\Sigma M_{i}=E \cdot g_{i}^{0,38} \cdot l_{i},
$$

where $g_{i}$ is the mass flow rate of the coolant in the area, $\mathrm{kg} / \mathrm{sec} ; l_{i}$ is the length of the section, $\mathrm{m} ; E$ is a correction factor [14]. 

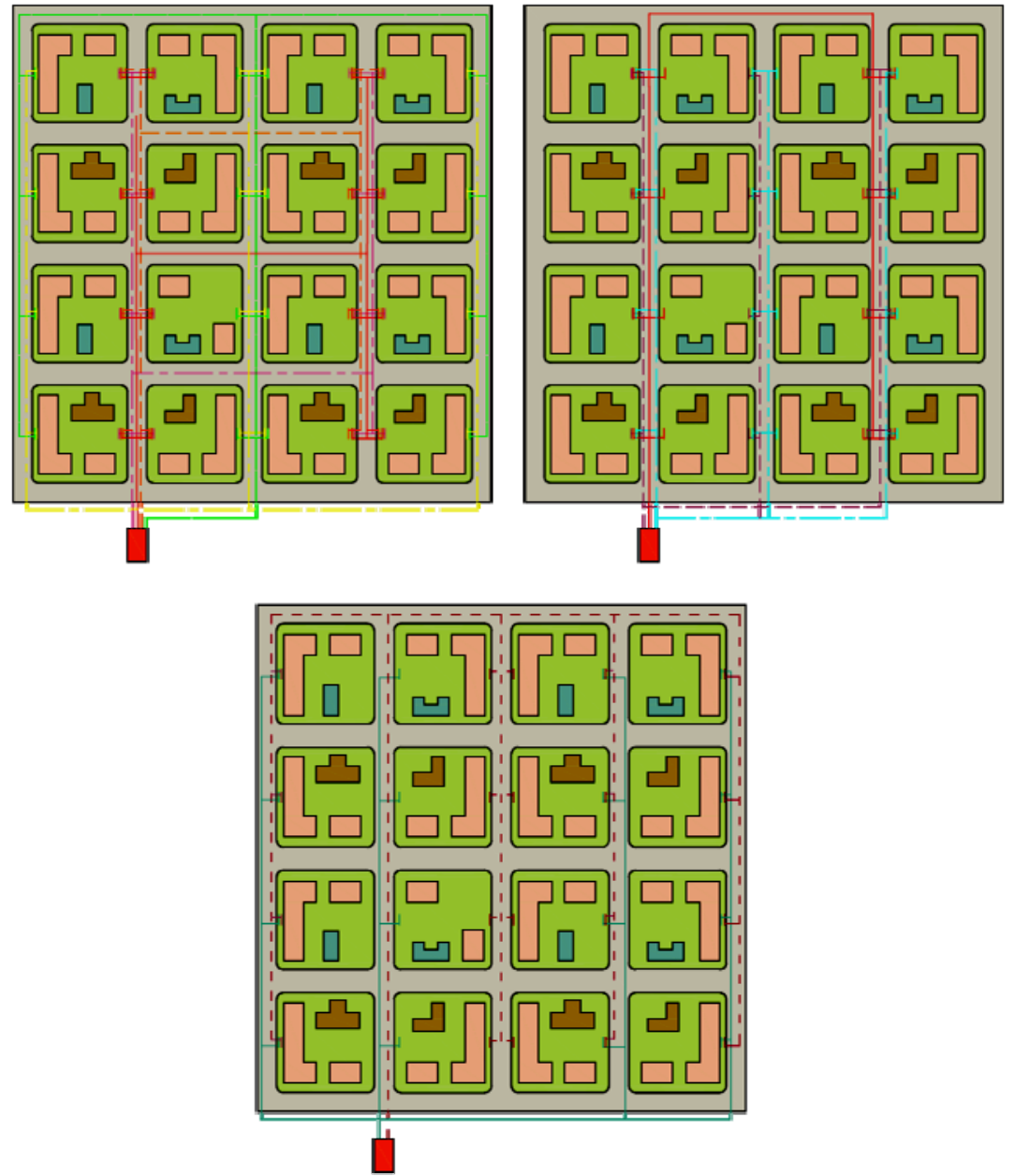

scheme № 1: - scheme № 2: scheme № 3: - - — scheme № 4:

scheme № 5: - - - scheme № 6: scheme № 7: - scheme № 8: scheme № 9: - scheme № 10:

- a heat generating source

Fig. 1. The options of planning a heating network

In this case, it should be noted that dependence (1) is valid for a constant flow rate of the coolant in the considered section of the pipeline. Thus for its application it is necessary to divide the entire network into sections with $g_{i}=$ const. In [11] it is noted that this indicator does not fully reflect the characteristics of an extensive network. For such networks, a parameter called the moment of heat load seems more informative. It reflects the heat load of an area as concentrated at the points of connection to heat supply systems and equals the product of the distance from the heat source to consumers by the heat load of this consumer. In this case, it is proposed to calculate the distances by rays, which is not in line with the actual conditions for laying the route. It is proposed to accommodate this inaccuracy by replacing the ray lengths 
with the actual length of pipeline sections obtained following preliminary tracing $[9,11]$ and the formula for determining the actual moment of heat load will be as follows:

$$
Z_{\phi}=\Sigma z_{i}=\Sigma\left(Q_{i}^{p} \cdot l_{\phi i}\right)
$$

where $z_{i}$ is the value of the actual moment of the heat load on the area, MWatt $\bullet \mathrm{m} ; Q_{i}^{p}$ is the calculated heat load in the considered area, MWatt; $l_{\phi i}$ is the actual length of the section, $\mathrm{m}$.

According to the enlarged parameter considered in [5], the annual heat losses of the heating network largely depend on the material characteristics, i.e., under equal operating conditions and the same climatic parameters, they depend on the heat exchange surface and can be given by the formula

$$
q_{m . n}=q \cdot M_{y c},
$$

where $q$ are specific annual heat losses related to $1 \mathrm{~m}^{2}$ of conditional material characteristics of the heating network, Gcal/(year $\left.\cdot \mathrm{m}^{2}\right) ; M_{y c}$ is a conditional material characteristic of the heating network calculated on the outer surface of the insulation, $\mathrm{m}^{2}$ :

$$
M_{y c}=M+0.15 \Sigma l_{i} .
$$

The results of a numerical study of the above enlarged parameters for the considered routing options (provided that the heat load is uniformly distributed over the area of the microdistrict) are presented in Fig. 2.

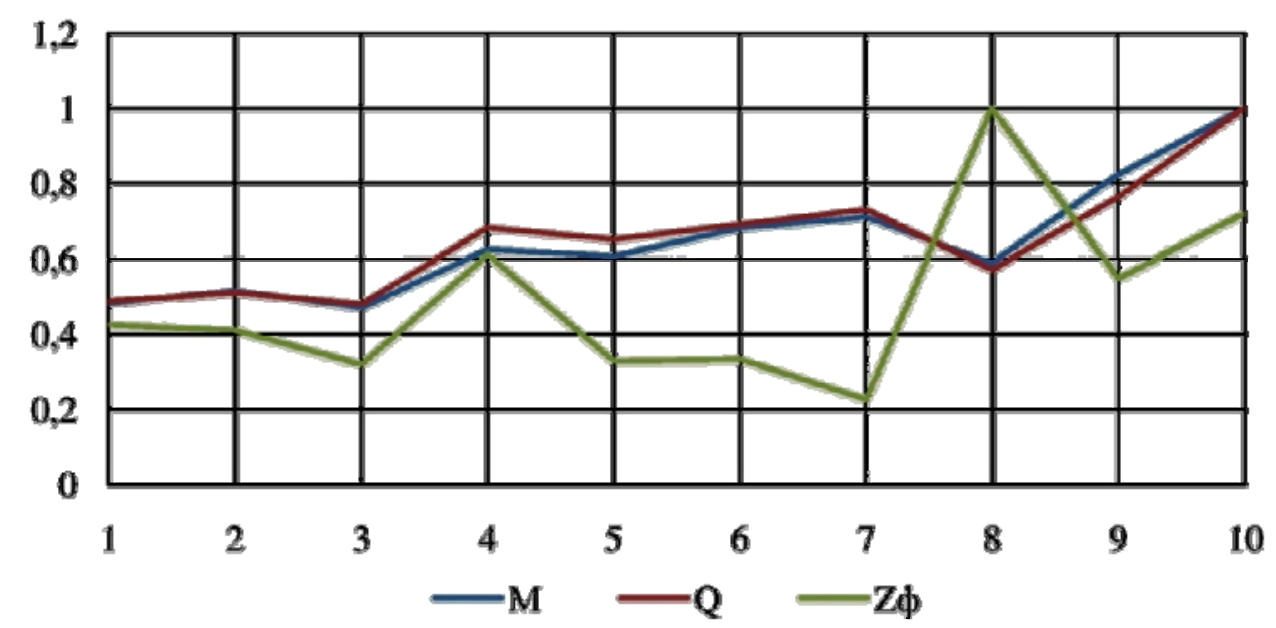

Fig. 2. Change in material characteristics $M$, heat losses $Q$ and the actual moment of the heat load Zph depending on the routing options

In Fig. 2 it can be seen that some options for routing the heating network are more advantageous from the point of view of one parameter and less advantageous from the point of view 
of the other parameters. This is even clearer in the graph in Fig. 3 where the most profitable options are selected according to various parameters referred to as the least profitable.

E.g., scheme 3 is more preferable in terms of material characteristics and heat losses but is less preferable in terms of the actual moment of heat load where scheme 7 seems more advantageous. In the meantime scheme 8, which is the least profitable in terms of the actual moment of heat load, has quite acceptable indicators in terms of heat loss parameters and material characteristics. This confirms the obvious fact that a variant that is optimal in one parameter does not have to be optimal in the others.

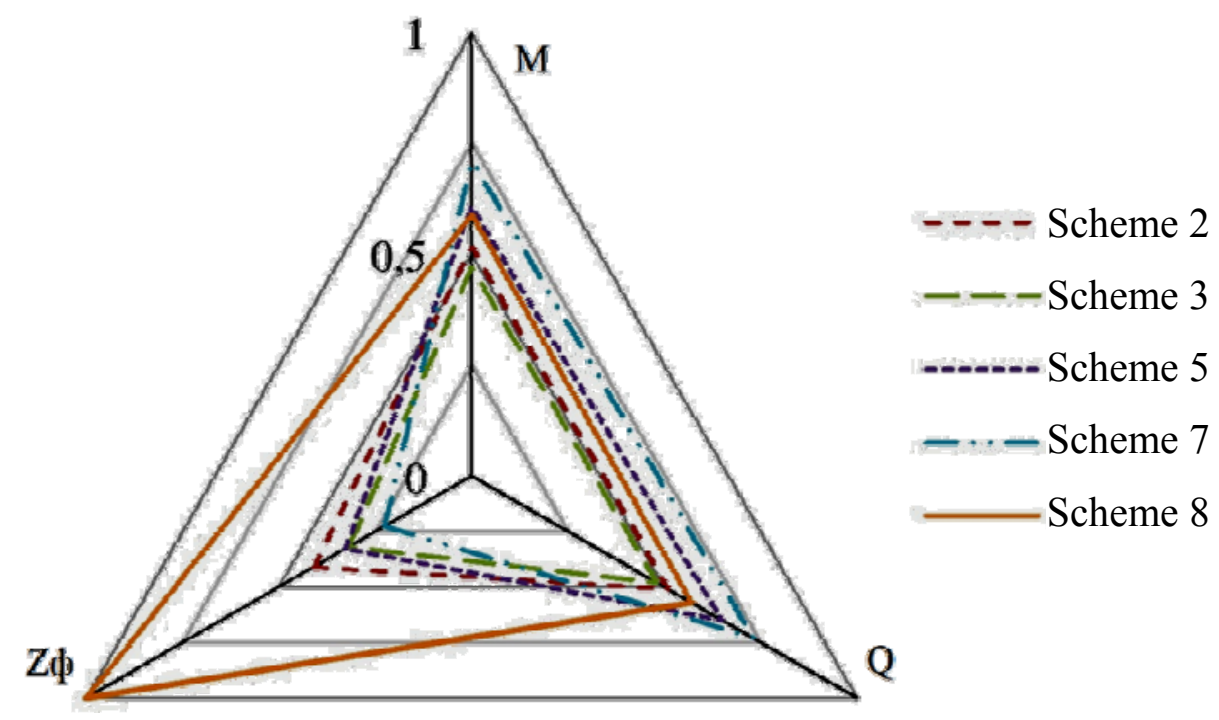

Fig. 3. Diagram of optimal options for routing a heating network

In view of such discrepancies, it is natural to use multi-criteria optimization in the problem of tracing heat pipes.

\section{Statement of a multicriteria problem in identifying the best route for a heating net-}

work. Comparison of individual options for laying a heating network is proposed to be performed by introducing parameters $p_{k}$ of relative importance or weight estimates for each of the specified aggregated criteria and obtaining an integral (total) optimality indicator for each of the options.

Let us note that from the practical formulation of such a problem it is clear that the values of all criteria are positive. At the same time, it is desirable to minimize some of them in the process of integral optimization (e.g., the parameters $M, Z_{\phi}, q_{m . n}$ ), while the values of other criteria, on the contrary, should be (if possible) increased (these include, e.g., the parameters of reliability or profitability ) [10]. 
In order to simplify the discussions (while maintaining their general character), it is proposed to replace the values of all criteria from the first group, e.g., by their reciprocal values $x_{k} \rightarrow 1 / x_{k}$. In the process of optimization it will become desirable to increase all criteria updated in this way and the sum (integral criterion) such as

$$
S=\sum_{k=1}^{n} x_{k} p_{k}
$$

Note 1. The choice of the "inverting" replacement of criteria must be associated with the subsequent recalculation of the weighted estimates $p_{k}$. This requires evaluation by an expert who is well aware of the physical aspects of the problem.

The above can be formalized and reduced to the consideration of the following mathematical problem. The multidimensional space $R^{n}=\left\{\left[x_{1}, \ldots, x_{n}\right]\right\}$ has a positive cone:

$$
C=\left\{\left(x_{1}, \ldots, x_{n}\right), x_{k}>0\right\},
$$

and it contains a (large) discrete set of points (vectors) $M=\left\{M_{j}, 1 \leq j \leq N\right\}$. In addition, an ndimensional vector of "coordinate priorities" is given also lying in the cone $C$. It is required to identify a point (or a cloud of points) from a given set $M$ whose radius vector has the maximum scalar product (5) with the vector $\bar{p}$.

Note 2. The vector of weights (priorities) is typically normalized in some way. E.g., the sum of all the coordinates of this vector is often assumed to equal unity (probabilistic normalization).

Note 3. In [1] looking at problems of multi-criteria optimization, the below criterion (5) is called an additive criterion of optimality. The literature (see, e.g., [3, 4, 19, 12]) generally discusses numerous integral criteria collected in the process of multi-criteria optimization from several simpler ones (such as the above criteria (1), (2), (4)).

Below is considered only the criterion (5) as it is our belief that in specific (rather highly specialized) optimization problems its detailed study may be more useful than elaborations $[3,4,12,19]$ on fuzzy preferences of some (local) criteria rather than others. In such tasks, expert (weighted) evaluations offered by professionals should have a fairly clear role to play and not be subject to momentary preferences. Accordingly, the approach that brings many criteria into one seems to be quite functional and deserving of (relative) credibility.

Certainly over time or when there are significant reasons for re-evaluating the weights, changes can be made to them. But it appears sensible to apply the system of the integral crite- 
rion in different examples of the same type of highly specialized problems and to collect some statistics on their solution by means of this approach. If these statistics turn out to be unsatisfactory and come under a lot of criticism, it will certainly be necessary to consider (within the framework of more general approaches) improving it.

Considering the scalar product used in the formula (5), it can be written as follows

$$
S=|\bar{x}||\bar{p}| \cos \varphi \text {. }
$$

Therefore it is simpler in the study of this problem to normalize the vector using the quadratic (Euclidean) norm:

$$
|\bar{p}|=\|\bar{p}\|_{2}=\sqrt{\sum_{k} p_{k}^{2}}
$$

rather than a more visual linear one:

$$
\|\bar{p}\|_{1}=\sum_{k} p_{k}
$$

Traditional (probabilistic) weighting factors assigned by experts on the condition

$$
\sum_{k} p_{k}=1
$$

can easily be replaced by the Euclidean set by extracting the roots

$$
q_{k}=\sqrt{p_{k}},
$$

so for new weights

$$
\sum_{k} q_{k}^{2}=1
$$

From a formal mathematical point of view, the problem is not challenging: for a fixed vector, enumeration of even a large number of vectors (in order to find the maximum of expression (5) or (7) for this set) is easy to algorithmize. Let us note the considerations that make it easy to visualize the search for a point with the maximum value of expression (7) (among the set of points from a given cloud).

3. Example of visualization of the problem. Let us discuss a set of 10 traces discussed in Section 1 . The similarity of the graphs of the material characteristic $M$ and heat loss $Q$ in Fig. 2 suggests the expediency of first considering not three-factor rather than two-factor optimization associated with the material characteristic $M$ and the moment of the heat load $Z_{\phi}$. Comparing each trace with a pair of coordinates $\left(1 / Z_{\phi} ; 1 / M\right)$, we get a cloud of 10 points in the plane. In the example, let us set the weights of two factors equal to $p_{1}=0.8$ and $p_{2}=0.6\left(p_{1}^{2}+p_{2}^{2}=1\right) \mathrm{p} 1=0.8$ and $\mathrm{p} 2=0.6$ and identify the point with the largest value of the sum (7) in this cloud. 
Considering a unified length

$$
|\bar{p}|=\|\bar{p}\|_{2}=1
$$

of the weight vector $\left(p_{1}, p_{2}\right)$ the expression (7) is simplified to

$$
S=|\bar{x}| \cos \varphi \text {. }
$$

Using the known dependencies of flat geometry, we get the formulas

$$
x_{1}=\rho \cdot \cos \varphi, x_{2}=\rho \cdot \sin \varphi, \text { где } \rho=|\bar{x}|=\sqrt{x_{k}^{2}},
$$

that connect the polar and Cartesian coordinates in the plane $\mathbb{R}_{x_{1} x_{2}}^{2}$. This allows us to interpret expression (10) as the first of two coordinates of a fixed point in a Cartesian coordinate system, whose first axis (and at the same time the polar axis) is directed along the vector $p=\left(p_{1}, p_{2}\right)$.

Of all the straight lines drawn through 10 points of the cloud perpendicular to the vector axis $\bar{p}$, the farthest from the origin is the straight line $l_{7}$ passing through the point $\mathrm{A}_{7}(4.8 ; 1.3)$. It is this point that yields the maximum to the expression (10) which is equal to 4.62.

\begin{tabular}{|c|c|c|c|}
\hline $\begin{array}{c}\text { Number } \\
\text { of the } \\
\text { scheme }\end{array}$ & $1 / Z_{\phi}$ & $1 / M$ & $S$ \\
\hline 1 & 2.4 & 2 & 3.12 \\
\hline 2 & 2.5 & 1.9 & 3.14 \\
\hline 3 & 3.3 & 2 & 3.84 \\
\hline 4 & 1.6 & 1.4 & 2.12 \\
\hline 5 & 3.3 & 1.5 & 3.78 \\
\hline 6 & 3.3 & 1.4 & 3.48 \\
\hline 7 & 4.8 & 1.3 & 4.62 \\
\hline 8 & 1 & 1.6 & 1.76 \\
\hline 9 & 1.6 & 1.2 & 2.00 \\
\hline 10 & 1.4 & 1 & 1.72 \\
\hline
\end{tabular}

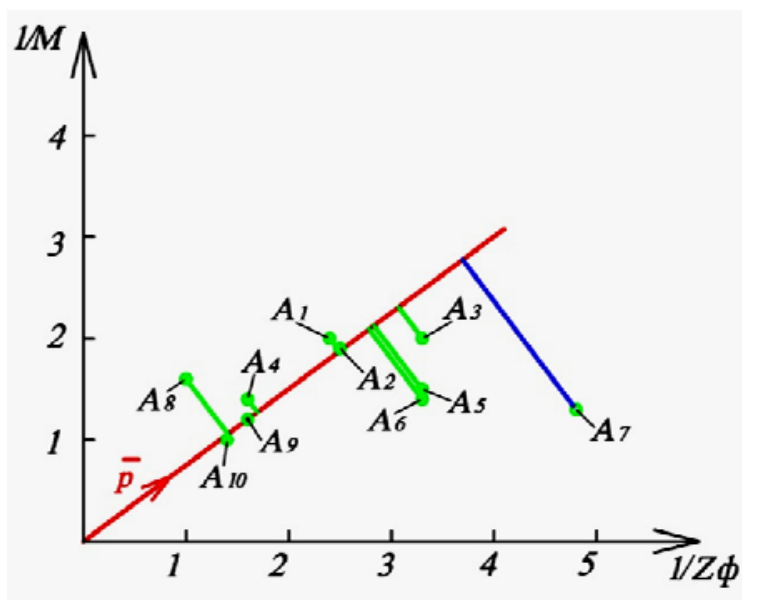

Fig. 4. Weight vector $\bar{p}$ and a cloud of 10 points according to the two parameters $Z_{\phi}$, $M$

Moving from the simple example in the problem with two factors (criteria) to the general situation, similar ideas can be employed. Instead of straight lines perpendicular to the axis of the weight vector, in a visual interpretation of a multi-criteria problem, the reference (tangent) hyperplanes to a given cloud of points, also perpendicular to the axis can be discussed. The point of the cloud through which the reference plane farthest from the origin passes gives the maximum expression (7) or (10). 
In this case, it may be advised to replace the initial multidimensional point cloud, e.g., with a convex polyhedral hull of such a cloud. Note that algorithms for constructing such polyhedra have been sufficiently investigated in computational geometry (see, e.g., [2]).

In conclusion, an example of a visual three-factor interpretation of the above problem with 10 tracing options will be provided. Assuming, e.g., the coordinates of the weight vector equal to $p_{1}=0.71, p_{2}=0.57, p_{3}=0.43\left(p_{1}^{2}+p_{2}^{2}+p_{3}^{2}=1\right)$, some reference planes will be shown in Fig. 5.

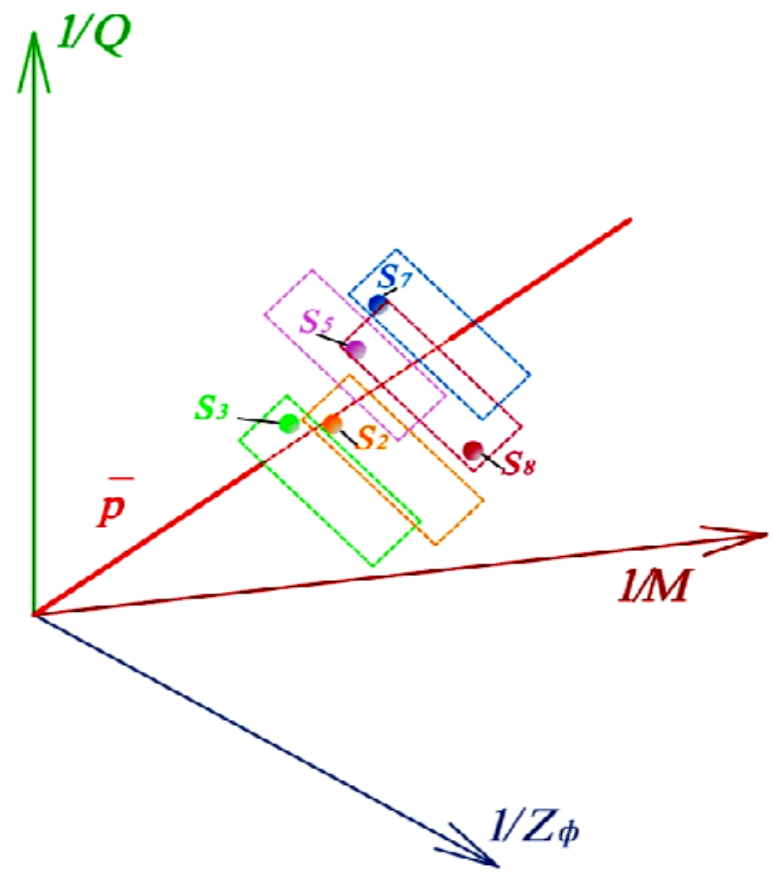

Fig. 5. Weight vector $\bar{p}$ and a cloud of 5 points according to the three parameters $M, Z_{\phi}, Q$

Calculation of the sums of the form (5) for 10 different variants yields the following values:

$$
\begin{aligned}
& S_{1}=3.704 ; S_{2}=3.675 ; S_{3}=4.343 ; S_{4}=2.549 ; S_{5}=3.860 ; \\
& S_{6}=3.743 ; S_{7}=4.708 ; S_{8}=2.310 ; S_{9}=2.379 ; S_{10}=1.994 .
\end{aligned}
$$

This sum takes the greatest value (as in the two-factor model) for the $7^{\text {th }}$ tracing option. If the weighted estimates (note that only their model variants were considered) were adequately introduced, variant 7 can be considered best.

Let us also emphasize the importance of the scales of different (e.g., in the physical sense) criteria in such optimization problems. If in the last consideration we keep the parameters $M$ and $Q$ but increase, e.g., all the values of $Z_{\phi}$ three-fold (and thus decrease their inverse values three-fold), the best of 10 will be the $3^{\text {rd }}$ tracing option, and the $7^{\text {th }}$ option will no longer be the best. 


\section{Conclusions}

1. In the multi-criteria problem of identifying the best route for a heating network, it is necessary to minimize one part of the criteria and maximize the other. The suggested transformation of some of the criteria by their reciprocal values $x_{k} \rightarrow 1 / x_{k}$ allows one to unify the problem.

2. The suggested replacement of the traditional linear norm in the study of a multi-criteria optimization problem by a quadratic (Euclidean) one with the subsequent recalculation of weights provides a clear procedure for identifying a solution to the problem.

3. The above examples show the importance of the correct choice of scales and assignment of weights in optimization problems. These operations should be conducted by experts who are aware of their importance and role in such studies.

\section{References}

1. Batishchev D. I., Shaposhnikov D. E. Mnogokriterial'nyi vybor s chetom individual'nykh predpochtenii [Multi-criteria selection with even individual preferences]. N. Novgorod, IPF RAN Publ., 1994. 92 p.

2. Berg M., Cheong O., Krevel'd M., Overmars M. Vychislitel'naya geometriya. Algoritmy i prilozheniya [Computational geometry. Algorithms and applications]. Moscow, DMK Press Publ., 2016. 438 p.

3. Blyumin S. L., Shuikova I. A. Modeli i metody prinyatiya reshenii v usloviyakh neopredelennosti [Models and methods of decision-making under uncertainty]. Lipetsk, LEGI Publ., 2001. 138 p.

4. Gitis L. Kh. Statisticheskaya klassifikatsiya i klasternyi analiz [Statistical classification and cluster analysis]. Moscow, Izd-vo Moskovskogo gosudarstvennogo gornogo universiteta, 2003. 157 p.

5. Ionin A. A., Khlybov B. M., Bratenkov V. H., Terletskaya E. H. Teplosnabzhenie [Heat supply]. Moscow, Stroiizdat Publ., 1982. 336 p.

6. Kashirin M. A., Kitaev D. N. Vybor optimal'noi trassy teplovykh setei prompredpriyatiya [Choosing the optimal route for industrial heating networks]. Gradostroitel'stvo. Infrastruktura. Kommunikatsii, 2018, no. 2 (11). pp. $9-12$.

7. Kobelev V. N. Vybor optimal'noi struktury teplovykh setei. Diss. kand. tekhn. nauk [Choosing the optimal structure of heating networks. Cand. eng. sci. diss.]. Kursk, 2011. 129 p.

8. Mednikova E. E., Stennikov V. A., Postnikov I. V. Razrabotka metodiki otsenki effektivnosti prisoedineniya novykh potrebitelei $\mathrm{k}$ teplosnabzhayushchei sisteme [Development of methods for evaluating the effectiveness of connecting new consumers to the heat supply system]. Promyshlennaya energetika, 2018, no. 2, pp. 13 -20.

9. Mel'kumov V. N., Kuznetsov S. N., Tul'skaya S. G., Chuikina A. A. Vliyanie planirovki funktsional'nykh zon gorodov na razvitie sistem teplosnabzheniya [Influence of planning of functional zones of cities on the development of heat supply systems]. Nauchnyi zhurnal stroitel'stva i arkhitektury, 2019, no. 1 (53), pp. 116-123.

10. Mel'kumov V. N., Sklyarov K. A., Tul'skaya S. G., Chuikina A. A. Kriterii optimal'nosti i usloviya sravneniya proektnykh reshenii sistem teplosnabzheniya [Optimality criteria and conditions for comparison of design solutions for heat supply systems]. Nauchnyi zhurnal stroitel'stva i arkhitektury, 2017, no. 4 (48), pp. 29-37. 
11. Papushkin V. N. Radius teplosnabzheniya. Khorosho zabytoe staroe [Radius of heat supply. Well forgotten old]. Novosti teplosnabzheniya, 2010, no. 9, pp. 44-49.

12. Romanova I. K. Ob odnom podkhode k opredeleniyu vesovykh koeffitsientov metoda prostranstva sostoyanii [On an approach to determining the weight coefficients of the state space method]. Nauka i obrazovanie, 2015, no. 4, pp. $105-129$.

13. Sachivka V. D. Modeli i metody vybora optimal'nogo sposoba prokladki podzemnykh inzhenernykh kommunikatsii v usloviyakh gorodskoi zastroiki [Models and methods for choosing the optimal method for laying underground utilities in urban development]. Gornyi informatsionno-analiticheskii byulleten', 2011, no. 12 , pp. $359-360$.

14. Sokolov E. Ya. Teplofikatsiya i teplovye seti [Heating and heating networks]. Moscow, MEI Publ., 2001. 472 p. 15. Stennikov V. A., Sennova E. V., Oshchepkova T. B. Metody kompleksnoi optimizatsii razvitiya teplosnabzhayushchikh sistem [Methods of complex optimization of development of heat supply systems]. Izvestiya Rossiiskoi akademii nauk. Energetika, 2006, no. 3, pp. 44-54.

16. Stennikov V. A., Barakhtenko E. A., Sokolov D. V. Razrabotka modifitsirovannogo metoda mnogokonturnoi optimizatsii dlya opredeleniya optimal'nykh parametrov truboprovodnykh sistem [Development of a modified multi-loop optimization method for determining the optimal parameters of pipeline systems]. Promyshlennaya energetika, 2018, no. 1, pp. 28-35.

17. Stennikov V. A., Barakhtenko E. A., Sokolov D. V. Razrabotka modifitsirovannogo metoda mnogokonturnoi optimizatsii dlya opredeleniya optimal'nykh parametrov truboprovodnykh sistem [Methods of complex optimization of development of heat supply systems]. Promyshlennaya energetika, 2018, no. 1, pp. 28-35.

18. Atavin A. A., Novitskii N. N., Sukharev M. G. e.a. Truboprovodnye sistemy energetiki: Matematicheskie $i$ komp'yuternye tekhnologii intel-lektualizatsii [Energy pipeline systems: Mathematical and computer technologies of intellectualization]. Novosibirsk, Nauka Publ., 2017. 384 p.

19. Novitskii N. N., Sukharev M. G., Tevyashev A. D. e.a. Truboprovodnye sistemy energetiki: metodicheskie $i$ prikladnye problemy matematicheskogo modelirovaniya [Pipeline energy systems: methodological and applied problems of mathematical modeling]. Novosibirsk, Nauka Publ., 2015. 476 p.

20. Khamkhanova D. N. Teoreticheskie osnovy obespecheniya edinstva ekspertnykh izmerenii [Theoretical basis for ensuring the unity of expert measurements]. Ulan-Ude, Izd-vo VSGTU, 2006. 170 p.

21. Chicherin S. V. Kommunal'naya teplosnabzhayushchaya infrastruktura dlya obespecheniya ustoichi-vogo razvitiya gorodov [Municipal heat supply infrastructure for sustainable urban development]. Gradostroitel'stvo. Infrastruktura. Kommunikatsii, 2017, no. 3 (8), pp. 9-14.

22. Chuikina A. A., Bokhan A. R., Grigor'eva K. A. Issledovanie svyazi material'noi kharakteristik teplovoi seti i momenta teplovoi nagruzki [Investigation of the relationship between the material characteristics of the heat network and the moment of heat load]. Gradostroitel'stvo. Infrastruktura. Kommunikatsii, 2018, no. 4 (13), pp. 9-16. 23. Mel'kumov V. N., Chujkin S. V., Papshickij A. M., Sklyarov K. A. Modelling of Structure of Engineering Networks in Territorial Planning of the City. Russian Journal of Building Construction and Architecture, 2015 , no. 4 , pp. $33-40$. 